\title{
Analysis of the Relationship between Monetary Policy and Stock Market Liquidity
}

\author{
Feng Liang* \\ The University of Queensland, Brisbane 4072, Queensland, Australia \\ *Corresponding author: Feng Liang, 1023002688@qq.com
}

\begin{abstract}
After the $19^{\text {th }}$ National Congress of the Chinese Communist Party, the introduction of the economic theory has promoted the integration of the global socialist market economy. Thereafter, this integration of the domestic and international market has been preliminarily completed, the role of the factor market in resource allocation has been improved, and a sturdy environment has been established for the development of Chinese enterprises. With the effective implementation of a series of policies after the financial system reform, the roles of the financial market in regulating macro-economy and revitalizing the market have become increasingly prominent. In regard to that, it has effectively promoted the financial market as a trade to "enrich people." This paper analyzes the relationship between monetary policy and stock market liquidity in terms of the influence of the former on the latter and suggests strategies to enhance the liquidity effect of monetary policy.
\end{abstract}

Keywords: Monetary policy; Stock market; Mobility; Relationship

Publication date: June 2021; Online publication: June 30, 2021

\section{Introduction}

Liquidity is defined as the ease or ability of assets to achieve effective realization without affecting its market price. Specifically, liquidity refers to the relationship between investment time scales and price scales. In practical terms, liquidity has two forms. The first is used in macro economy while the other is applied to the stock market. Using macroeconomic liquidity as an example, when there is a large amount of money, but the investments are relatively low, this will cause an overheated economy which is evident in the rise of prices. In short, the amount of money in the market is higher than the actual demand of money circulation. On the other hand, using stock market liquidity as an example, when the total market value and over the counter (OTC) funds in the trading capital remain unchanged but the growth rate of the standard stock supply is lower than that of the trading capital, the stock prices will rise. However, the profits of the listed companies would decline or remain the same.

\section{Impact of Monetary Policy on Securities Market}

In the stock market, the transmission of monetary policy needs to be realized via two links of liquidity effect (the interaction mechanism among money supply, securities market, and real economy).

First, when the central bank adjusts the money supply, the investors in the stock market would have certain psychological expectations. Secondly, the adjustments of money supply will convey the objectives of monetary policy to the real economy via the stock market. For example, when the central bank issues one yuan, it will go up four times after it is in the market. If the objective of the central bank in monetary policy adjustments is to raise the money supply, the liquidity of the stock market will increase. In terms of psychological expectations, investors will then think that stock prices may rise driven by investments. In the real economy, there will be an increase in consumption demands according to investment stimulus. In 
simple terms, investments are often used to stimulate consumption among consumers. In the two liquidity effects mentioned, monetary policy promotes the circulation of social funds via the impact on securities market to achieve the success and development of the overall economy.

\section{Countermeasures to Enhance the Liquidity Effect of Monetary Policy 3.1. Improve laws and regulations as well as financial system}

The financial system is a guarantee for the development of the national economy and an important way to ascertain the wealth of the people. At present, the reform of the financial system on the rule of law has produced excellent results. The financial management system and mechanism in the perspective of detailed laws and regulations should be improved whereby the development of the rule of law should be integrated with the establishment of credit mechanism. In terms of specific operations, severe punishment should be imposed to ensure that illegal operations in the financial market would be terminated. On the other hand, in regard to the information disclosure system in combination with the legislative work of the securities market, there is a need to refine this system to ensure the financial statements of listed enterprises correspond with their business situations.

\subsection{Use of interest rates to break the liquidity gap}

Interest rate marketization is a lever to break the liquidity shortage of the money market and securities market. With the adjustments of interest rate benchmarks, the central bank would be able to effectively play a role in benefiting the financial market. Based on the supply and demand of the capital market as well as the money market interest rates, the central bank can efficiently adjust the deposit and loan interest rates of financial institutions. Therefore, the interest rate formation mechanism should be reasonably implemented while establishing a flawless market interest rate system. At present, China is vigorously promoting digital currency and developing their infrastructure construction. The " $14^{\text {th }}$ Five-Year Plan" strengthens the constraints in the development of the relationship between digitization and new infrastructures. Therefore, in view of expanding infrastructure investments, the rational use of interest rate formation mechanism is beneficial in solving issues pertaining to debts and eventually, promote the overall economic development.

\subsection{Contingent decision-making and stock market adjustments}

After the subprime mortgage crisis in the United States, the disconnect between the real economy and financial markets has piqued the interests of economists. At present, the adjustments of the stock market are based on the principle of contingent decision-making. For example, when the market is in recession, the public's investment cost is usually reduced by adjusting the relevant tax rates. When speculative behaviors increase, the relevant tax rates are adjusted to prevent the effect of bubbles in the market. However, the roots of income inequality and the gap between the rich and the poor are still caused by the concentrated distribution of social wealth. Therefore, in order for effective contingent decision-making, there is a need for integration of the real economy, tax system, tax rates, redistribution of social wealth to solve income gaps, further expansion of the allocation efficiency of the factor market, as well as implementing diversified investments among the people.

\section{Conclusion}

In short, the relationship between monetary policy and stock market liquidity is vital as it involves the growth of the national economy and the fulfillment of the goal in enriching people. The current economic development has proved that the establishment of credit mechanism based on the rule of law, public awareness, social wealth redistribution, as well as the innovation and development of financial markets are factors that ensure the liquidity effect of monetary policy. Therefore, in the new era of the overall economic 
development, the real economy should be the basic foundation. Then, combining with the total material value of the national economy, monetary easing and monetary tightening policies should be applied appropriately while reasonably controlling the amount of money and expanding the role of the securities market.

\section{Disclosure statement}

The author declares no conflict of interest.

\section{References}

[1] Liu MZ, 2021, Analysis of macroeconomic fluctuation and mixed monetary policy framework. China Civil and Commercial, 18(2): 9-10.

[2] Ruan Q, 2021, Monetary policy, bond financing maturity and liquidity risk of securities companies. Wuhan Finance, 4(2): 44-45.

[3] Du LB, 2021, Research on the influence of social financing structure on the effectiveness of monetary policy. Journal of Shandong University of Business and Technology, 35(1): 79-90. 